Article

\title{
Nitrogen Removal Efficiency and Microbial Community Analysis of a High-Efficiency Honeycomb Fixed-Bed Bioreactor
}

\author{
Jie Xu 1,2,3,4,5, Chao Zhu ${ }^{3}$, Yi Liu ${ }^{4,5}$, Guanghui Lv ${ }^{1,2}$, Changyan Tian ${ }^{4,5, *}$ and Hongrui Ma ${ }^{3, *}$ \\ 1 College of Resources and Environment Science, Xinjiang University, Urumqi 830046, China; \\ xujie16@mails.ucas.edu.cn (J.X.); ler@xju.edu.cn (G.L.) \\ 2 Key Laboratory of Oasis Ecology of Ministry of Education, Xinjiang University, Urumqi 830046, China \\ 3 School of Environmental Science and Engineering, Shaanxi University of Science \& Technology, \\ Xi'an 710021, China; zhuchao@sust.edu.cn \\ 4 State Key Laboratory of Desert and Oasis Ecology, Xinjiang Institute of Ecology and Geography, \\ Chinese Academy of Sciences, Urumqi 830011, China; liuyi@ms.xjb.ac.cn \\ 5 University of Chinese Academy of Sciences, Beijing 100049, China \\ * Correspondence: tianchy@ms.xjb.ac.cn (C.T.); mahr@sust.edu.cn (H.M.)
}

Received: 18 May 2020; Accepted: 23 June 2020; Published: 26 June 2020

\begin{abstract}
Based on the concept of microbial community multi-processing in integrated spatial bacterial succession (ISBS), this study constructs a highly efficient cellular fixed-bed bioreactor that follows the growth of biological flora in the wastewater treatment process. The reactor is organically partitioned based on synergistic laws and in accordance with environmental and microbial metabolic changes, and sewage is subjected to unitized and specialized biological treatment under direct current conditions. The results show that the ISBS reactor exhibits stable nitrogen removal performance under a low-carbon source. Compared with traditional sewage biochemical treatment technology, the microbial concentration is increased by 2-3 times and even up to 12 times, and the ammonia nitrogen removal rate is maintained at $99 \%$. The removal rate reaches $90 \%$ (hydraulic retention time of $14 \mathrm{~h}$ ). High-throughput sequencing analysis based on $16 \mathrm{~S}$ rDNA reveals the microbial community structure succession at different depths of the same section of the reactor. The microbial community is rich under the influence of environmental factors and exhibits different responses. The intervals vary. An analysis of the microbial community function explains why the ISBS reactor has high nitrogen removal efficiency.
\end{abstract}

Keywords: cellular fixed bed bioreactor; ammonia oxidation; microbial community structure; biofilm

\section{Introduction}

The biochemical method is a common advanced approach for urban sewage treatment. The concept of biological control of the entire process has been gradually developed for the treatment of industrial wastewater. The state has strict standards for total nitrogen (TN) in wastewater discharge [1,2]. The biochemical method has become one of the most economical and effective methods of wastewater denitrification. Nitrogen is used as organic nitride and ammonia nitrogen in wastewater. Organic nitrogen is mainly present in the form of proteins and amino acids. Biological nitrogen removal in wastewater decomposes nitrogen-containing organic matter under the action of microorganisms in the treatment process, converts it to $\mathrm{N}_{2}$, and releases it from the liquid phase [3].

Given that the biochemical method needs to prevent microorganisms in the reactor from escaping, a high biomass concentration must be maintained in the bioreactor, and the induction and generation of excess activated sludge must be avoided. Currently, most of the biomass is recycled from secondary or 
tertiary sedimentation tanks to the initial stage of purification. However, the high nutrient concentration in sewage exerts a "shock effect" on nitrifying bacteria [4]. The refluxing biomass interferes with the natural nutrient chain due to changes in nutrient and oxygen concentrations in the reactor, thus reducing the denitrification performance of the reactor $[5,6]$. The biological process of removing organic nitrogen compounds involves the stages of ammonization, nitrification, and denitrification. The rate of ammonization and denitrification is much higher than that of nitrification, thus making nitrification a constraint stage in the entire reaction process. Owing to the slow growth of nitrifying bacteria [7], when a general suspension growth system is used for nitrification, the processing capacity of the system cannot easily recover within a short time once sludge loss occurs. Although using biofilm reactors as nitrification units can solve sludge loss, biofouling occurs on the surface of inert carriers [8,9], and periodic regeneration is required to ensure the proper operation of the processing equipment.

Biofouling also occurs in membrane bioreactors (MBRs) [10]. Microorganisms must be controlled to prevent membrane fouling. Studies have shown that population effects (quorum sensing (QS)) have been successfully applied to control the formation of biofilms on medical devices and plant tissue surfaces [11]. After introducing bacterial QS to control fouling in an MBR, Wong et al. [12] used enzymes with an affinity for macromolecules to promote cell degradation for a short catalytic lifetime and loss of free enzymes. The use of supplemental exohydrolase to enhance the hydrolysis of microbial macromolecules can improve membrane performance after the destruction of the fouling layer. Goldman et al. [13] reported that MBR performance was improved after using phage during treatment, and adhesion of microorganisms to the membrane surface was remarkably reduced. When a bioreactor is supplemented with phage, membrane permeability increases by a factor of three and biofouling is reduced by $40 \%$.

Given the shortcomings of existing membrane bioreactors caused by the difficulty of controlling the core biological factors, such as microbial community, metabolic activity, and membrane biomass, the effluent fluctuates easily, the membrane is contaminated rapidly, and the technology becomes complicated [14,15]. The current study proposes the concept of integrated spatial bacterial succession (ISBS) to construct a high-efficiency honeycomb fixed-bed bioreactor that divides the traditional "hybrid" microbial treatment model into multiple continuous intervals. The constructed reactor has a fixed biomass and aeration system. During sewage treatment, the sewage flows continuously along an open curve under the action of gravity, and the curve is divided into multiple sections. The water quality parameters change continuously along the direction of the water flow but do not change with time, thus providing a stable environment for the growth of microorganisms [16,17]. After the operation stabilizes, theoretically, succession occurs in the microbial community structure of different biofilms, and the metabolic function interval is eliminated. Core nitrification and auxiliary zones are formed, thereby realizing stepwise metabolism of the matrix in the sewage and efficiently removing carbon and ammonia. Unlike traditional sewage biochemical treatment technology, the biofilm microbial concentration in each interval is improved due to the special growth of interval microorganisms. Moreover, the ISBS reactor provides an independent space for microbial communities with specific metabolic kinetic energy by controlling the metabolic activity/community composition of microorganisms, hence microorganisms in a single interval coordinate mutually when "food" is limited. Theoretically, the problem of biofouling can be eliminated to prevent the excessive formation of biofilms [18].

In this study, a high-efficiency honeycomb fixed-bed bioreactor was built for a pilot project. After determining the operating environment parameters of the reactor (dissolved oxygen (DO), $\mathrm{pH}$, and temperature), microorganisms were collected by measuring the water quality changes in inlet and outlet water. A community sample was used to analyze the relationship between denitrification efficiency and the microbial community of the ISBS reactor, and multi-treatment interval succession integration of the microbial community was demonstrated. 


\section{Materials and Methods}

\subsection{Reactor Setup and Operation}

A pilot-scale IBSS-type (honeycomb) bioreactor was constructed with a width of $3.2 \mathrm{~m}$ and length of $10.5 \mathrm{~m}$. The cross-section of the reactor was $3.2 \mathrm{~m}$ wide, $1.75 \mathrm{~m}$ long, and $2.4 \mathrm{~m}$ deep, and the effective volume was $80 \mathrm{~m}^{3}$, as shown in Figure 1.

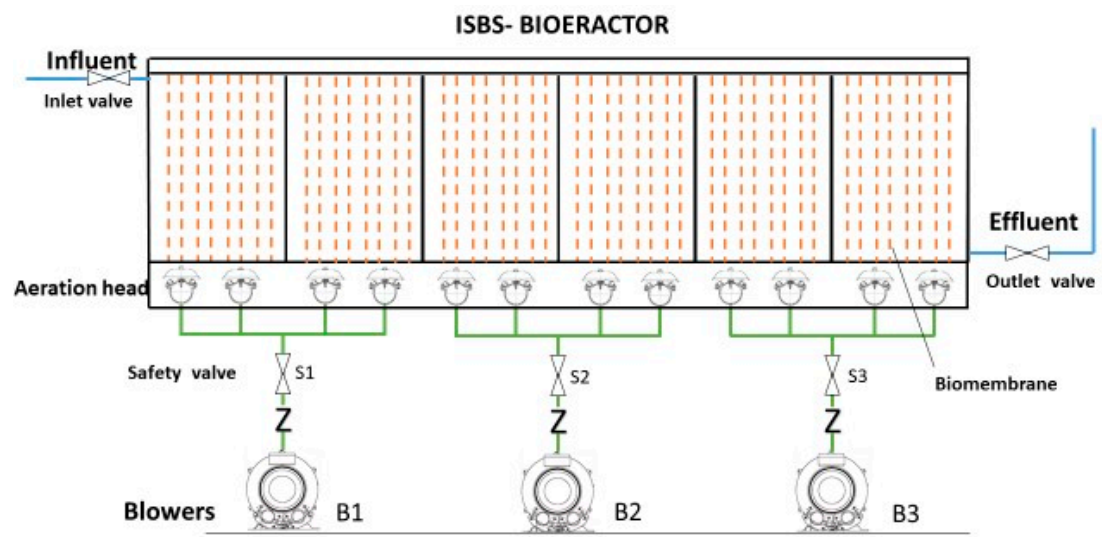

Figure 1. Schematic diagram of integrated spatial bacterial succession (ISBS) device.

The ISBS reactor was made of epoxy-coated steel, and it was divided into six continuous sections. The effective volume of each section was similar, and sewage flowed continuously along an open curve under the action of gravity. The curve flowed continuously as a plug-flow reactor, and it was divided into multiple segments. The water quality parameters changed with the direction of the water flow but not with time, thus providing a stable environment for the growth of microorganisms. The whole system had been operating stably for at least 3 months before the study was conducted.

Municipal sewage was used as the reactor sewage. The chemical oxygen demand (COD) of treated sewage influent water ranged within $100-500 \mathrm{mg} \cdot \mathrm{L}^{-1}$, and that of effluent was reduced to less than $25 \mathrm{mg} \cdot \mathrm{L}^{-1}$. The most important component of this technology is the high-efficiency honeycomb fixed bed. The other process equipment included a screen, a grit chamber, and an aeration device. The characteristics of influent water quality under different conditions are shown in Table 1.

Table 1. Influent water quality characteristics.

\begin{tabular}{ccccc}
\hline Parameter & Unit & $\begin{array}{c}\text { Ave } \\
\text { (Average) }\end{array}$ & $\begin{array}{c}\text { Min } \\
\text { (Minimum) }\end{array}$ & $\begin{array}{c}\text { Max } \\
\text { (Maximum) }\end{array}$ \\
\hline $\mathrm{COD}$ & $\mathrm{mg} \cdot \mathrm{L}^{-1}$ & 302 & 128 & 448 \\
$\mathrm{~N}-\mathrm{NH}_{3}$ & $\mathrm{mg} \cdot \mathrm{L}^{-1}$ & 29.0 & 20.5 & 39.3 \\
$\mathrm{TSS}$ & $\mathrm{mg} \cdot \mathrm{L}^{-1}$ & 212.7 & 145 & 317 \\
$\mathrm{DO}$ & $\mathrm{mg} \cdot \mathrm{L}^{-1}$ & 4.8 & 4.6 & 4.9 \\
\hline
\end{tabular}

\subsection{Engineering Debugging}

In the engineering commissioning phase, the temperature of the input-treated sewage should be more than $16{ }^{\circ} \mathrm{C}$ to ensure superior conditions required for the cultivation of biomes, and the $\mathrm{pH}$ should be 7-8 $[19,20]$. During the inoculation process in the current study, activated sludge was slowly injected into the water inlet of the bioreactor, and the biofilm of the reactor zone was not damaged during the entire process. The inoculation volume was close to the volume of the two reaction zones of the bioreactor $\left(26 \mathrm{~m}^{3}\right)$.

Aeration was initiated in the bioreactor after the activated sludge filled the first two consecutive reaction zones. The aeration system in these two zones was confirmed to be working properly by 
monitoring the pressure in the air line and the blower flow meter. The sewage passed through the bioreactor in quantities ranging from $15 \%$ to $20 \%$ of the maximum daily flow (21-28 $\mathrm{m}^{3} /$ day). Given such a flow rate, the bioreactor was operated for $4-6 \mathrm{~h}$. Then, $15-20 \%$ of water was added every 4-6 h. During the commissioning process at that flow rate, the purification of each section of the bioreactor could be adjusted, the consequences of possible untreated sewage emergency discharge could be reduced, the sewage flow could be adjusted, and cultivation and domestication could be achieved. Moreover, the amount of aeration could be adjusted to ensure that the desired set of sewage treatment quality indicators was achieved.

After the bio-community in the bioreactor was loaded and fixed, water was fed continuously from the sewage pipe network to the reactor. The water flow status of the bioreactor was set, and the water intake was gradually increased. Through the air-regulating valve, the air intake amount at each stage of the purification process was adjusted in accordance with the load change in the pollutants in each reaction section of the bioreactor. The quality of influent water was regularly checked during commissioning, and the activated sludge fixation status of the bioimplant monitoring frame in each zone of the bioreactor was determined. Qualitative and quantitative assessments of the tested bacteria were conducted in reference to the previous literature to reveal the biological characteristics of the microbial community, and the water retention time of $14 \mathrm{~h}$ was set in accordance with the site conditions [21-23]. The ammonia nitrogen of the effluent was less than $1 \mathrm{mg} \cdot \mathrm{L}^{-1}$, COD was less than $30 \mathrm{mg} \cdot \mathrm{L}^{-1}$, and the quality of the effluent did not fluctuate significantly after 3 consecutive days, proving that the commissioning process was over and the official operation had begun.

We used the new carrier (MIC) from SVERIT Ltd. of Russia. The characteristics of the new carrier are shown in Table 2: the specific surface area (BET) was $252 \mathrm{~m}^{2} / \mathrm{g}$, the effective area of the biofilter with a bioreactor net volume of $80 \mathrm{~m}^{3}$ was $20,160 \mathrm{~m}^{2}$, the average MIC organic contamination load was $96 \mathrm{~kg} \mathrm{COD} /\left(\mathrm{m}^{3} \cdot\right.$ day $)$, and the volume load was $112 \mathrm{~kg} /\left(\mathrm{m}^{3} \cdot\right.$ day $)$

Table 2. Characteristics of the carriers.

\begin{tabular}{ccccc}
\hline Sample & $\begin{array}{c}\text { Specific Surface } \\
\text { Area (BET) } \mathbf{~ m}^{2} / \mathbf{g}\end{array}$ & $\begin{array}{c}\text { The Total Effective Area } \\
\text { of the Biofilter } \mathbf{~}^{2}\end{array}$ & $\begin{array}{c}\text { Volume Load } \\
\mathbf{k g} /\left(\mathbf{m}^{3} \cdot \mathbf{d}\right)\end{array}$ & $\begin{array}{c}\text { Organic Load kg } \\
\mathbf{C O D} /\left(\mathbf{m}^{3} \cdot \mathbf{d a y}\right)\end{array}$ \\
\hline MIC & 252 & 20,160 & 112 & 96 \\
\hline
\end{tabular}

\subsection{Sample Collection, DNA Extraction, and High-Throughput Sequencing}

Biomass samples were collected from different sections of the ISBS reactor and at different levels after 200 days of operation to characterize the microbial community structure via high-throughput sequencing. Sampling points were set, and sampling was conducted in the upper $(10 \mathrm{~cm})$, middle $(120 \mathrm{~cm})$, and lower $(230 \mathrm{~cm})$ parts of all six reaction zones during stable operation of the reactor to obtain 18 sludge samples. The samples were filtered through filter paper $(11 \mathrm{~cm}, 45 \mu \mathrm{m})$ and weighed $(0.20-0.25 \mathrm{~g})$ for DNA extraction. The concentration and total amount of DNA were detected using a NanoDrop instrument. Genomic DNA was extracted with the Power Soil DNA isolation kit (Mobio, CA, USA) and diluted to $10 \mathrm{ng} \cdot \mu \mathrm{L}^{-1}$ for subsequent analysis.

Amplification of bacterial 16S rRNA gene was performed, and universal primers $11 \mathrm{~F}$ (5'-GTTTGATCCTGGCTCAG-3') and 1492r (5'-TACCTTGTTACGACTT-3') were used for highthroughput sequencing, as performed in the work of Lee et al. [24,25].

\subsection{Analytical Methods}

All water samples were filtered through a $0.45 \mu \mathrm{m}$ filter prior to chemical analysis. The biochemical oxygen demand (BOD), suspended solids (SS), COD, and TN and total phosphorous (TP) content in the samples were measured in accordance with the Chinese national environmental protection standard (2013). DO and $\mathrm{pH}$ were determined using oxygen and $\mathrm{pH}$ probes, respectively (WTW $\mathrm{pH} / \mathrm{Oxi} 340 \mathrm{i}$, WTW, Germany). 
Canonical correspondence analysis (CCA) with the Canoco package was used for evaluation, and the parametric test was replaced with the Monte Carlo test to evaluate the responses of all parameters.

\section{Results and Discussion}

\subsection{Biomass Accumulation in ISBS Reactor for Pre-Denitrification}

For the reactor, the effective volume of daily domestic sewage flow was $80 \mathrm{~m}^{3}$ and the specific surface area of the MIC was $252 \mathrm{~m}^{2} / \mathrm{g}$. The effective area of the biofilter was $20,160 \mathrm{~m}^{2}$, the volume load was $112 \mathrm{~kg} /\left(\mathrm{m}^{3} \cdot\right.$ day $)$, and the organic load was $96 \mathrm{~kg} \mathrm{COD} /\left(\mathrm{m}^{3} \cdot\right.$ day $)$. Through calculation, we determined that the effective concentration of biomass in the ISBS bioreactor was $34.8 \mathrm{~g} / \mathrm{m}^{2}$. There was no cumulative gain of biomass on the surface area of the MIC of the inert carrier. In the reaction interval, the relationship between "microbial food" and the number of bacterial cells is controlled by the effective surface of the multilayer inert carrier and the rate of digestible nutrients [26]. The main part of the nutrient is used only to maintain energy; it is insufficient for bacterial cell growth, and the bacteria cells are starved. In this state, the growth of microorganisms does not cause the generation of excess activated sludge. Given that the growth rate depends on the amount of "food" in the reaction interval, the number of microorganisms does not increase (fixed growth period). The growth rate is reduced due to the high density of biomass on the carrier. As indicated above, most organic and inorganic contaminants are used only to maintain existing biofilms. Therefore, the bacterial cells self-regulate in accordance with the environmental structure of each reaction zone [27].

\subsection{ISBS Reactor}

The ISBS reactor was operated for over 365 days. The HRT of the ISBS reactor was $14 \mathrm{~h}$, and the quality of the inlet and outlet water for 120 days is shown in Figure 2. The water COD concentration was $278 \pm 255 \mathrm{mg} \cdot \mathrm{L}^{-1}$, and ammonia nitrogen was $14 \pm 12 \mathrm{mg} \cdot \mathrm{L}^{-1}$. As shown in Figure 2, within 120 days, the quality of the inlet water became increasingly obvious, but the effluent water quality was stable. The effluent COD concentration was $19 \pm 7 \mathrm{mg} \cdot \mathrm{L}^{-1}$, and the ammonia nitrogen was $0.33 \pm 0.15 \mathrm{mg} \cdot \mathrm{L}^{-1}$.

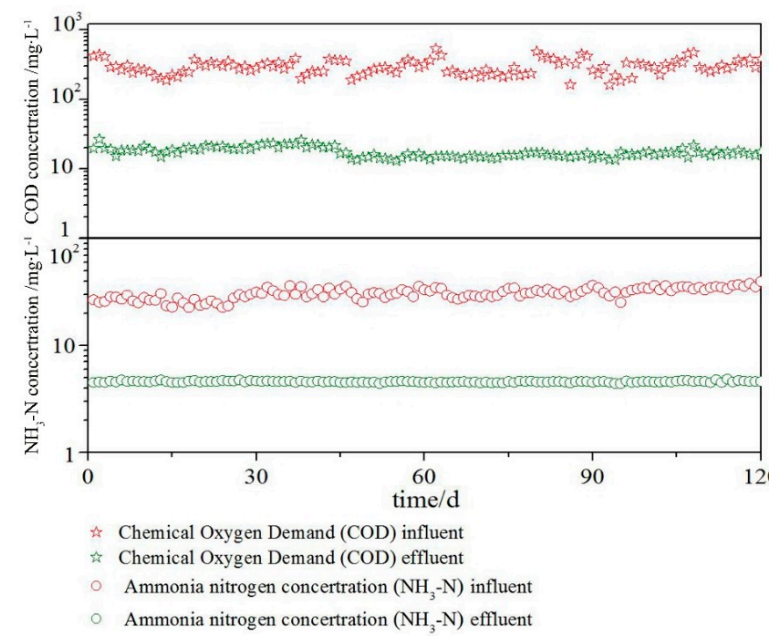

Figure 2. The performance of the ISBS reactor on chemical oxygen demand (COD) and ammonium removal during long-term (120 days) operation.

\subsection{Changes in $C O D, B O D$, and Ammonia Nitrogen at Different Intervals}

Samples were obtained from the inlet and outlet points of each reactor to compare the performance in different areas. Figure 3 shows the influent water quality of the ISBS reactor during short-term stable operation. The influent COD concentration was $345 \pm 84 \mathrm{mg} \cdot \mathrm{L}^{-1}$, and the ammonia nitrogen was $35 \pm 6 \mathrm{mg} \cdot \mathrm{L}^{-1}$. 


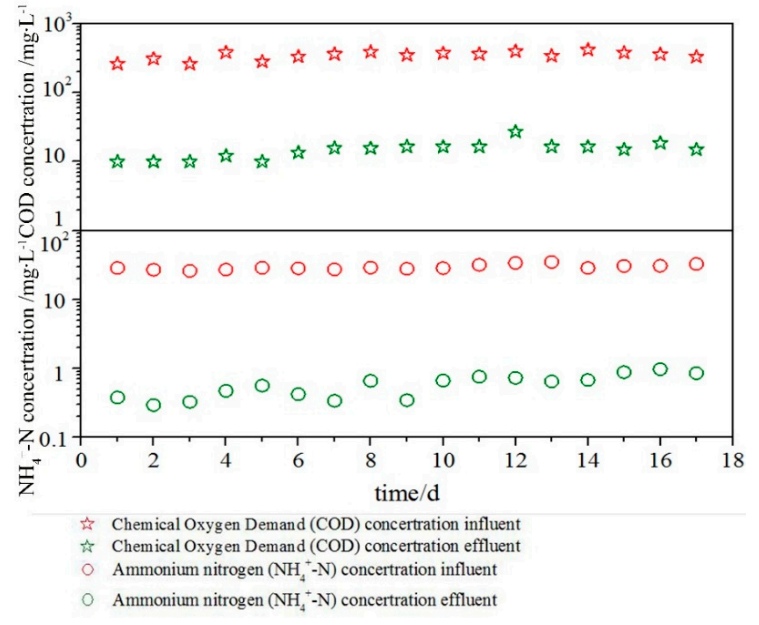

Figure 3. The performance of the ISBS reactor on COD and ammonium removal during short-term (17 days) operation.

Figure 4 shows the changes in $\mathrm{COD}, \mathrm{BOD}, \mathrm{N}^{-\mathrm{NH}_{4}}{ }^{+}, \mathrm{DO}$, and $\mathrm{pH}$ on a random day during the short-term stable operation of the ISBS reactor. The COD concentration in each reaction zone (R1-R6) continuously decreased, and the influent COD concentration was $395 \mathrm{mg} \cdot \mathrm{L}^{-1}$. The COD concentration in the six reaction zones was $171,125,102,68,54$, and $23 \mathrm{mg} \cdot \mathrm{L}^{-1}$, and the final effluent was $23 \mathrm{mg} \cdot \mathrm{L}^{-1}$; these results indicate that the COD concentration deceased by $56.70 \%, 11.6 \%, 5.8 \%, 8.6 \%, 3.5 \%$, and $7.8 \%$, respectively, compared with the influent concentration. The total COD removal rate of the ISBS reactor reached $94.2 \%$ because the effluent from each reaction zone was the influx of the next zone.

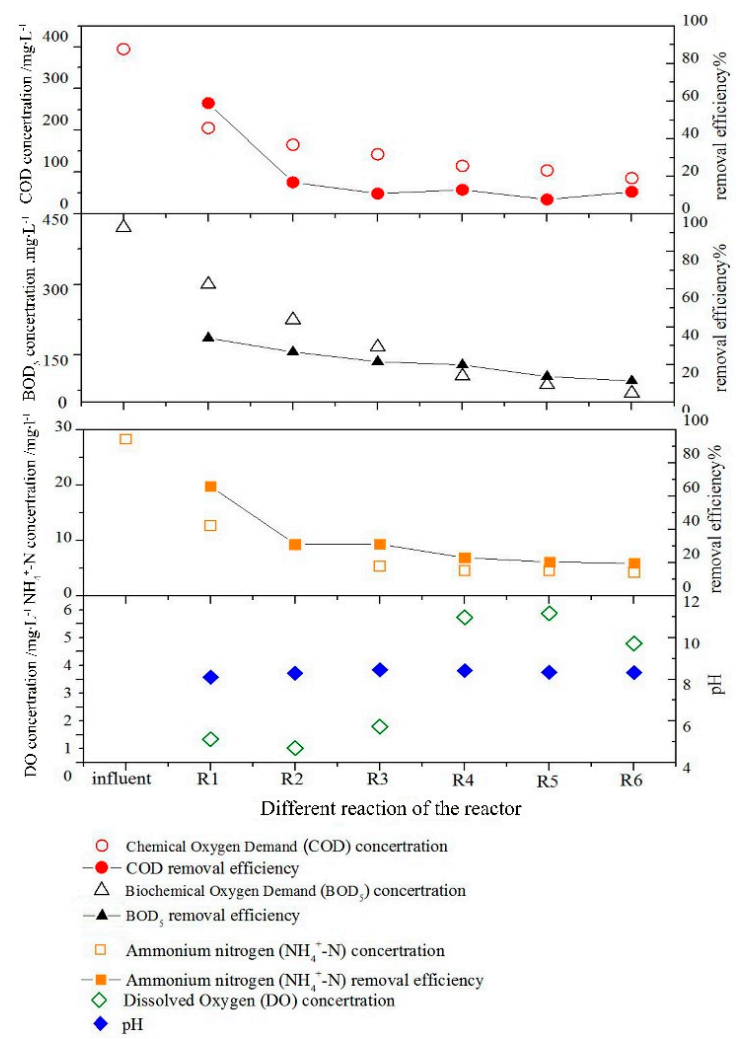

Figure 4. Variation of effluents in different reaction cellular of the ISBS reactor.

In reaction $\mathrm{R} 1$, ammonia nitrogen decreased from $28.89 \mathrm{mg} \cdot \mathrm{L}^{-1}$ to $10.5 \mathrm{mg} \cdot \mathrm{L}^{-1}$, and the degradation rate was $64.8 \%$. $\mathrm{BOD}_{5}$ decreased by $32.1 \%$. In theory, the oxygen demand of nitrifying $1 \mathrm{~g}$ of ammonia nitrogen is $4.5 \mathrm{~g}$ (calculated together with nitrification and nitrosation) [28]; in reality, the oxygen 
demand of nitrifying $1 \mathrm{~g}$ of ammonia nitrogen was $1.14 \mathrm{~g}$. About $70.9 \%$ of DO was used for nitrification in reaction R1 in this study; hence, with the same aeration, the amount of DO measured in reaction R1 was small (Figure 4). DO is one of the key factors that affect nitrification [27]. The digestion reaction requires a large amount of oxygen, and it affects $\mathrm{BOD}_{5}$ depending on the type and quantity of microorganisms and the degree of biochemical reaction. At reactions R5 and R6, the amount of growth was small due to the low concentration of ammonia nitrogen and nitrosation of single cells, nitrifying bacteria, and autotrophic microorganisms [29]. The change in quantity had almost no effect on oxygen demand. Even at a low $\mathrm{BOD}_{5}$ value, nitrifying bacteria can survive and nitrification occurs. Overall, the removal rate of ammonia nitrogen in the ISBS reactor was stable above $99 \%$.

ISBS reactors are highly efficient. The effluent water quality in these reactors is more stable than that in moving-bed and rope-bed biofilm reactors [30-32]. ISBS reactors are effective in COD removal and have higher efficiency in removing ammonia nitrogen compared with magnetic activated sludge sequencing. The performance of these reactors is much better than that of conventional sequencing batch reactors [33] and mixed membrane bioreactors. ISBS reactors require a small amount of water retention time but exhibit high COD and ammonia nitrogen removal efficiency [34]. The main indicators of effluent water quality meet the Class A emission requirements of the Pollutant Discharge Standards for Urban Sewage Treatment Plants (GB 18918-2002): COD $\leq 50 \mathrm{mg} \cdot \mathrm{L}^{-1}, \mathrm{NH}_{3}-\mathrm{N} \leq 5 \mathrm{mg} \cdot \mathrm{L}^{-1}$, $\mathrm{SS} \leq 10 \mathrm{mg} \cdot \mathrm{L}^{-1}$. ISBS reactors are more efficient than other reactors that are modified based on conventional biochemical methods $[35,36]$.

\subsection{Microbial Community Analysis at Different Reaction Intervals of the ISBS Reactor}

\subsubsection{Bacterial Community}

A difference was observed in the relative species richness of a single section of the reactor, as shown in Figure 5. The main dominant bacteria in the reactor were Proteobacteria, Bacteroides, and Firmicutes, which are rich in pre-species, and Nitrospira with high species richness at the late stage.

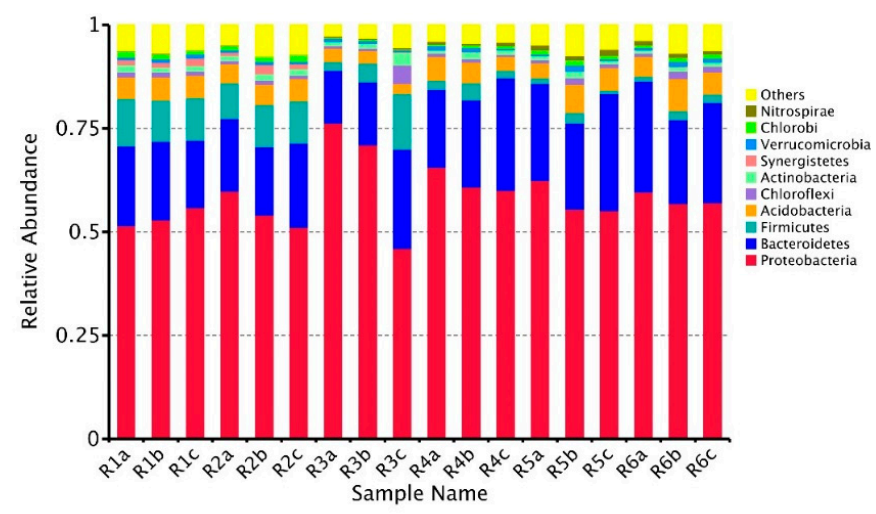

Figure 5. Variations of microbial relative abundance on the family level of different niches in cellular of the ISBS reactor (R1-R6 indicates different reaction intervals of the reactor and $a, b$, and c indicate the upper, middle, and lower parts of the reaction zone).

Proteobacteria account for a relatively large proportion of urban sewage treatment plants and sewage biological treatment equipment $[37,38]$. Proteobacteria are the dominant species in many wastewater treatment systems [39], accounting for 58.6\% in the reactor. Y-Proteobacteria and $\beta$-Proteobacteria are mostly facultative anoxic bacteria with breathing and fermentation metabolisms that have organic matter as their carbon source, which is the main participant in the degradation of COD in sewage treatment systems. Burkholderia, on the $\beta$-Proteobacteria branch, are the main flora in biofilm [40], and Y-Proteobacteria are the main microorganisms forming biofilm [41]. The species richness of Proteobacteria in each unit is moderate. 
Bacteroides account for about $20.9 \%$. They are an important member of heterotrophic organisms involved in the circulation of organic carbon and protein substances. They can hydrolyze complex organic substances, such as cellulose and starch, into monosaccharides and then re-digest them into lactic, acetic, formic, or pyruvic acid. The protein is hydrolyzed into amino and organic acids. Bacteroides hydrolyze sludge flocs, which play a role in the reduction of residual sludge and the evolution of microbial flora [42].

Firmicutes, with high species richness in the early stage, are the main bacteria that hydrolyze and acidify the substrate. The Bacillus strain is related to the degradation of COD and macromolecular organic matter, which is difficult to decompose [35]. The proportion of Firmicutes is $10.4 \%$, and the proportion of macromolecular organic matter and COD decreases to $1.8 \%$ at the late stage. At the same time, $1.1 \%$ Chloroflexi provides support for the structure of aerobic granular sludge in the form of floc skeletons in the sludge fungus flocs [43]. In ISBS reactors, these relatively large microorganisms coexist and have their own functions, which is one of the reasons such reactors can efficiently denitrify and remove pollutants.

The $a, b$, and $c$ axes in Figure 5 denote the relative species richness at the upper, middle, and lower depths of a single interval, respectively. The degree of species richness at different levels changed to some extent (Figure 5). In every cell, the scale of the Proteobacteria group at the lower layer of the vector was generally reduced by $3.9 \%$ compared with the upper layer. In the single interval, the lower-level deformed bacteria family was generally reduced by $3.9 \%$, compared with the upper layer. This result was due to the autotrophic process carried out by the Y-Proteobacteria and $\beta$-Proteobacteria groups. These microorganisms, which are collectively known as ammonia-oxidizing bacteria (AOB), were enriched by a large amount and consumed a large amount of oxygen. With the high-efficiency removal of ammonia nitrogen and the accumulation of nitrite, the amount of DO was small in the early stage of the reaction (Figure 2). Under the condition that the organic carbon source was sufficient, the place where DO was sufficient was highly favorable to Y-Proteobacteria and $\beta$-Proteobacteria groups; thus, the upper part of Proteobacteria in the same reaction interval was at a relatively high level [44]. With the accumulation of nitrite, the relative species richness of nitrifying spirulina in the late stage of the reaction began to increase (from $0.1 \%$ to $1.2 \%$ ), and Nitrospira, as nitrifying bacteria, oxidized nitrite to nitrate. Nitrification can maintain high activity in the presence of exogenous organic carbon, indicating that it is coordinated by autotrophic and heterotrophic bacteria in the ISBS reactor. The sufficient organic carbon in the reactor differed. Studies have pointed out that heterotrophic nitrifying microorganisms have advantages in removing ammonia nitrogen from polluted water and are an important component of activated sludge [45].

The species richness of Nitrospira was observed in the upper, middle, and lower parts of the reactor zone and showed a trend of decreasing then increasing. It was also affected by DO. Nitrospira grew easily where DO was high [46], and Bacteroides exhibited the same trend. This result proves that the microbes on the inert carrier were affected by the environment and exhibited different distributions in different parts, which was the reason the reaction interval presented different functions.

\subsubsection{Characteristics of Physical Community}

We used the PyNAST method [47] and mapped phylogenetic relationships and evolutionary trees of representative sequences (Figure 6). Each interval had the same core community, and the species richness of the R3 interval was high (Figure 6a). Bacterial communities, such as Proteobacteria, Bacteroides, and Firmicutes, were observed, and their levels were mainly reflected in Acinetobacter, Flavobacterium, and Ferruginibacter (Figure 6b). Figure $6 \mathrm{~b}$ has three layers. The innermost layer is a phylogenetic tree constructed based on the evolutionary relationship of representative OTU (operational taxonomic units) sequences. The different colors represent the corresponding genus levels. The second layer is the relative abundance of OTUs, and is represented by the column height. The outermost layer is the out-annotated credibility distribution, and the column height represents the confidence of the annotation. Acinetobacter is mainly involved in biodegradation, and it can remove several 
kinds of organic and inorganic man-made waste [48] and polyphosphorus [49]. The intracellular enzyme produced by Flavobacteria participates in enzymatic degradation of the polycyclic aromatic hydrocarbons phenanthrene and anthracene [50], indicating that Flavobacteria facilitates the degradation of environmental and food contaminants. Ferruginibacter is often the dominant species in membrane bioreactors [51]. The microorganisms cooperate with one another in an inert carrier to form the core of the ISBS reactor.

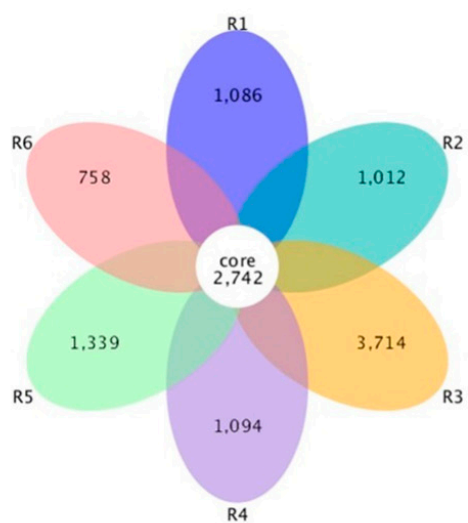

(a)
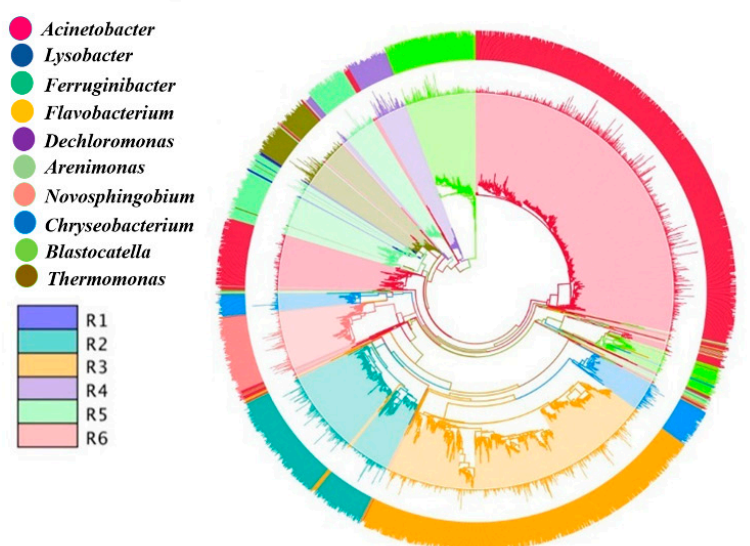

(b)

Figure 6. Operational taxonomic units (OTU)-based Venn diagram (a) and phylogenetic tree (b) of the microbial community in the ISBS reactor.

The microbial community varies in different reaction intervals and parts of the ISBS reactor. Although each reaction zone has the same core community, external conditions, such as DO and COD, affect the composition of microorganisms in different parts of the same carrier. Thus, the function of each section of the reactor changes according to the distribution of microorganisms.

\subsubsection{Canonical Correspondence Analysis (CCA)}

The different colors in Figure 7 represent the samples grouped into intervals (R1, R2, R3, R4, R5, and R6), and a, b, and c represent the upper, middle, and lower levels of intervals, respectively. The arrows denote different environmental factors. The length of the arrow connection represents the degree of correlation between an environmental factor and the community and species distributions. The longer the connection, the greater the impact of the environmental factor. These results indicate that COD, TSS (Total suspended solids), $\mathrm{NH}_{3}-\mathrm{N}$, and $\mathrm{NO}_{3}-\mathrm{N}$ had an intense effect, whereas DO had a minimal effect. R1, R2, and R3c were affected by COD, TSS, and $\mathrm{NH}_{3}-\mathrm{N}$, and R4, R5, R6, R3a, and R3b were obviously affected by $\mathrm{DO}$ and $\mathrm{NO}_{3}-\mathrm{N}$ environmental factors. Moreover, $\mathrm{DO}$ and $\mathrm{NO}_{3}-\mathrm{N}_{\text {were }}$ negatively correlated with COD, TSS, and $\mathrm{NH}_{3}-\mathrm{N}$.

The results prove that under the influence of environmental factors, the microbes in the ISBS reactor had different communities before and after reactions and exhibited different functions in different reaction intervals. This result is consistent with the outcome of the analysis of bacterial communities in reaction intervals (Figure 6). The analysis of the influence degree of environmental factors on different depths in the same reaction interval revealed differences in the microbial communities at different levels within the same range of the reactor. In the $\mathrm{R} 2$ reaction interval, COD had a greater impact on the upper microbial community and $\mathrm{NH}_{3}-\mathrm{N}$ had a great impact on the middle and bottom microbial communities, greater on the middle than on the bottom.

These results also prove that different aspects were emphasized in the microbial community composition in the same reaction interval. The microbial community in the inert carrier in the ISBS reactor had self-regulation and synergism effects, which was the reason the reactor could remove ammonia nitrogen efficiently. 


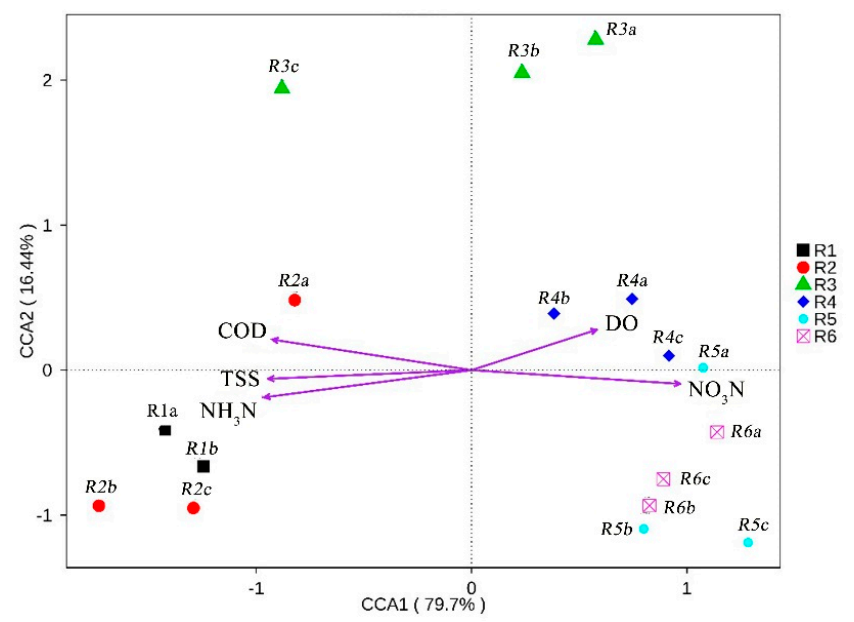

Figure 7. Canonical correspondence analysis (CCA) analysis of the environmental factors and microbial communities in different cellular of the ISBS reactor.

Microorganisms positively related to $\mathrm{COD}, \mathrm{NH}_{3}-\mathrm{N}$, and TSS, such as Acetanaerobacteria (Figure 8), can hydrolyze gelatin and esculin and ferment several monosaccharides, disaccharides, and oligosaccharides [52]. Christensenellace and Acetanaerobacteria have the same correlation with environmental factors, and other studies have indicated that Christensenellace is positively correlated with digestible dry matter and digestible organic matter intake [53]. Anaerovorax, which is positively correlated with $\mathrm{COD}, \mathrm{NH}_{3} \mathrm{~N}$, and TSS, is an organic anaerobic chemical nutrient bacterium [52]. Studies have shown that the functions of microorganisms are related to their correlation with environmental factors. If the content of organic substances, ammonia nitrogen, and TSS is high, then microorganisms will have sufficient "food" and be able to survive and reproduce easily. By contrast, these microorganisms are negatively correlated with $\mathrm{NO}_{3}-\mathrm{N}$ because a decrease in ammonia nitrogen is accompanied by an increase in $\mathrm{NO}_{3}-\mathrm{N}$ content and a decrease in COD and TSS. An increase in $\mathrm{NO}_{3}-\mathrm{N}$ content indicates that "food" that is positively related to COD, $\mathrm{NH}_{3}-\mathrm{N}$, and TSS is no longer sufficient, and the living environment has undergone adverse changes. Meanwhile, other microorganisms, such as Nitrospira and Cupriavidus, that are positively correlated with $\mathrm{NO}_{3}-\mathrm{N}$ have a good living space. Nitrospira is the main nitrous acid oxidizing bacteria in wastewater treatment [54], and its growth and reproduction must be accompanied by an increase in $\mathrm{NO}_{3}-\mathrm{N}$ content. After the consumption of easily degradable organic pollutants, Cupriavidus, a microorganism capable of degrading hydrazine and removing metal ions [55], exhibits room for growth.

The results of our study show that the microbial community was affected by environmental factors (COD, DO, and ammonia nitrogen) through the degradation of organic matter and ammonia nitrogen, and exhibited a synergistic effect and self-regulation at different intervals and depths. In different spaces of the ISBS reactor, the natural succession of microorganisms and the continuous coordinated growth according to the changes in space and the environment were the key factors for the good denitrification performance of the ISBS process. 


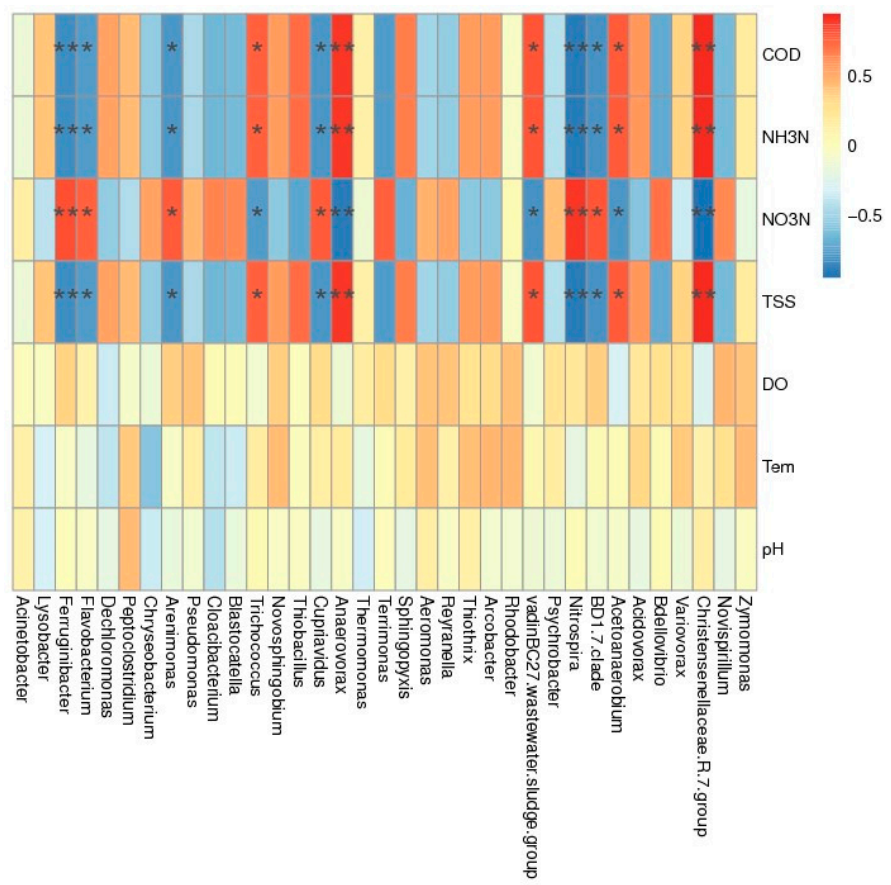

Figure 8. Clustering heat map based on the Spearman correlation analysis. The horizontal direction are the species, the longitudinal direction are the environmental factors, the heat map corresponds to the Spearman correlation coefficient $R$, and the $R$-value ranges from -1 to $1, R<0$ is a negative correlation, and $R>0$ is a positive correlation.

\section{Conclusions}

Ammonia-oxidizing bacteria (AOB) and some nitrite-oxidizing bacteria (NOB) belong to the group Proteobacteria, while Anammox bacteria belong to Planctomycetes, and other NOB belong to Nitrospirae. The species richness of Nitrospira was observed in the upper, middle, and lower parts of the reactor zone and showed a trend of decreasing, then increasing. For the whole ISBS reactor, proteus accounted for $58.6 \%$, among which Y-Proteobacteria and $\beta$-Proteobacteria were mostly facultative anaerobes with both a respiration and fermentation metabolism. For a single range, AOB are enriched in many microorganisms, and the Proteus in the lower layer is generally $3.9 \%$ less than that in the upper layer. It consumes a lot of oxygen and is accompanied by the efficient removal of ammonia nitrogen. Our study showed that the reason the ISBS reactor can remove ammonia nitrogen efficiently is the interaction of the microbial community. When the organic carbon source is high, Y-Proteobacteria and $\beta$-Proteobacteria remove ammonia nitrogen. When the organic carbon source and BOD are low, the nitrification of Spirillum by nitrifying bacteria completely degrades the remaining small amount of ammonia nitrogen and makes the ISBS reactor reach a high level of effective denitrification.

Author Contributions: Conceptualization, C.Z., H.M. and C.T.; methodology, C.Z. and C.T.; software, J.X. and C.Z.; validation, Y.L., H.M., C.T., G.L., C.Z. and J.X.; formal analysis, C.Z., H.M., C.T., G.L., Y.L. and J.X.; investigation, C.Z., H.M., C.T., G.L., Y.L. and J.X.; resources, C.Z., H.M., C.T., Y.L. and J.X..; data curation, C.Z.; writing-original draft preparation, J.X.; writing-review and editing, C.Z., H.M., C.T., G.L., Y.L. and J.X.; visualization, J.X.; supervision, C.Z., H.M., C.T.; project administration, J.X., C.Z., H.M., C.T.; funding acquisition, H.M. and C.T. All authors have read and agreed to the published version of the manuscript.

Funding: This research was funded by Major Science and Technology program for water pollution control and treatment (2017ZX07602-001-001) and Key project of the National Natural Science Foundation of China, grant number (U1803233).

Acknowledgments: We appreciate Major Science and Technology program for water pollution control and treatment, grant number (2017zx07602-001-001) and Key project of the National Natural Science Foundation of China, grant number (U1803233) for the financial founding provided. Special thanks to the Shaanxi University of Science \& Technology and Laboratory of industrial pollution control and resource utilization 1B423, 1B428 and ECOLAB laboratory 316. 
Conflicts of Interest: The authors declare no conflict of interest.

\section{References}

1. Chen, Z.; Kahn, M.E.; Liu, Y.; Wang, Z. The consequences of spatially differentiated water pollution regulation in China. J. Environ. Econ. Manag. 2018, 88, 468-485. [CrossRef]

2. Han, D.; Currell, M.J.; Cao, G. Deep challenges for China's war on water pollution. Environ. Pollut. 2016, 218, 1222-1233. [CrossRef] [PubMed]

3. Li, L.; Dong, Y.; Qian, G.; Hu, X.; Ye, L. Performance and microbial community analysis of bio-electrocoagulation on simultaneous nitrification and denitrification in submerged membrane bioreactor at limited dissolved oxygen. Bioresour. Technol. 2018, 258, 168-176. [CrossRef] [PubMed]

4. Yadu, A.; Sahariah, B.P.; Anandkumar, J. Influence of COD/Ammonia ratio on simultaneous removal of $\mathrm{NH}_{4}{ }^{+}-\mathrm{N}$ and COD in surface water using moving bed batch reactor. J. Water Process. Eng. 2018, 22, 66-72. [CrossRef]

5. Maharjan, A.K.; Kamei, T.; Amatya, I.M.; Mori, K.; Kazama, F.; Toyama, T. Ammonium-Nitrogen $\left(\mathrm{NH}_{4}{ }^{+}-\mathrm{N}\right)$ Removal from Groundwater by a Dropping Nitrification Reactor: Characterization of $\mathrm{NH}_{4}{ }^{+}-\mathrm{N}$ Transformation and Bacterial Community in the Reactor. Water 2020, 12, 599. [CrossRef]

6. Kato, H.; Fujimoto, H.; Yamashina, K. Operational Improvement of Main Pumps for Energy-Saving in Wastewater Treatment Plants. Water 2019, 11, 2438. [CrossRef]

7. Liu, Y.; Yang, S.F.; Tay, J.H. Improved stability of aerobic granules by selecting slow-growing nitrifying bacteria. J. Biotechnol. 2004, 108, 161-169. [CrossRef]

8. Song, W.; You, H.; Li, Z.; Liu, F.; Qi, P.; Wang, F.; Li, Y. Membrane fouling mitigation in a moving bed membrane bioreactor combined with anoxic biofilter for treatment of saline wastewater from mariculture. Bioresour. Technol. 2017, 243, 1051. [CrossRef]

9. Xiong, Y.H.; Liu, Y. Biological control of microbial attachment: A promising alternative for mitigating membrane biofouling. Appl. Microbiol. Biotechnol. 2010, 86, 825-837. [CrossRef]

10. Lee, J.; Kim, J.; Kang, I.; Cho, M.; Park, P.; Lee, C. Potential and limitations of alum or zeolite addition to improve the performance of a submerged membrane bioreactor. Water Sci. Technol. 2011, 43, 59-66. [CrossRef]

11. Baveja, J.; Willcox, M.; Hume, E.; Kumar, N.; Odell, R.; Poole-Warren, L. Furanones as potential anti-bacterial coatings on biomaterials. Biomaterials 2004, 25, 5003-5012. [CrossRef] [PubMed]

12. Wong, P.C.Y.; Lee, J.Y.; Teo, C.W. Application of dispersed and immobilized hydrolases for membrane fouling mitigation in anaerobic membrane bioreactors. J. Membr. Sci. 2005, 491, 99-109. [CrossRef]

13. Goldman, G.; Starosvetsky, J.; Armon, R. Inhibition of biofilm formation on UF membrane by use of specific bacteriophages. J. Membr. Sci. 2009, 342, 145-152. [CrossRef]

14. Li, W.; Zheng, P.; Zhang, J.; Shan, X.; Wang, Z.; Zhang, M. The effect of substrate concentration fluctuation on the performance of High-rate denitrifying reactor. Bioresour. Technol. 2014, 167, 53-60. [CrossRef] [PubMed]

15. Wang, L.; Liu, H.; Zhang, W.; Yu, T.; Jin, Q.; Fu, B.; Liu, H. Recovery of organic matters in wastewater by self-forming dynamic membrane bioreactor: Performance and membrane fouling. Chemosphere 2018, 203, 123. [CrossRef]

16. Zhang, L.; Lv, W.; Li, S.; Geng, Z.; Yao, H. Nitrogen Removal Characteristics and Comparison of the Microbial Community Structure in Different Anaerobic Ammonia Oxidation Reactors. Water 2019, 11, 230. [CrossRef]

17. Yao, R.; Yuan, Q.; Wang, K. Enrichment of Denitrifying Bacterial Community Using Nitrite as an Electron Acceptor for Nitrogen Removal from Wastewater. Water 2019, 12, 48. [CrossRef]

18. Bagheri, M.; Mirbagheri, S.A. Critical review of fouling mitigation strategies in membrane bioreactors treating water and wastewater. Bioresour. Technol. 2018, 258, 318. [CrossRef]

19. Almeida Fernandes, L.; Pereiraa, A.D.; Leala, C.D.; Davenportb, R.; Wernerb, D.; Filhoa, C.R.M.; Bressani-Ribeiroa, T.; Chernicharo, C.A.L.; de Araújo, J.C. Effect of temperature on microbial diversity and nitrogen removal performance of an anammox reactor treating anaerobically pretreated municipal wastewater. Bioresour. Technol. 2018, 258, 208-219. [CrossRef]

20. Yue, X.; Yu, G.; Liu, Z.; Tang, J.; Liu, J. Fast start-up of the CANOA process with a SABF and the effects of PH and temperature on nitrogen removal and microbial activity. Bioresour. Technol. 2018, 157-165. [CrossRef] 
21. Mannina, G.; Capodici, M.; Cosenza, A.; Trapani, D.D.; Ekama, G.A. The effect of the solids and hydraulic retention time on moving bed membrane bioreactor performance. J. Clean. Prod. 2018, 170, 1305-1315. [CrossRef]

22. Berkessa, Y.W.; Yan, B.; Li, T.; Tan, M.; She, Z.; Jegatheesan, V.; Jiang, H.; Zhang, Y. Novel anaerobic membrane bioreactor (AnMBR) design for wastewater treatment at long HRT and high solid concentration. Bioresour. Technol. 2018, 250, 281. [CrossRef]

23. Jiang, Q.; Ngo, H.H.; Nghiem, L.D.; Hai, F.I.; Price, W.E.; Zhang, J.; Liang, S.; Deng, L.; Guo, W. Effect of hydraulic retention time on the performance of a hybrid moving bed biofilm reactor-membrane bioreactor system for micropollutants removal from municipal wastewater. Bioresour. Technol. 2017, 247, 1228-1232. [CrossRef]

24. Lee, J.; Lee, J.W.; Kim, Y.M.; Park, C.; Park, K.Y. Performance and Fouling in Pre-Denitrification Membrane Bioreactors Treating High-Strength Wastewater from Food Waste Disposers. Water 2017, 9, 512. [CrossRef]

25. Youssef, N.; Sheik, C.S.; Krumholz, L.R.; Najar, F.Z.; Roe, B.A.; Elshahed, M.S. Comparison of species richness estimates obtained using nearly complete fragments and simulated pyrosequencing-generated fragments in 16s rRNA gene-based environmental surveys. Appl. Environ. Microb. 2009, 75, 5227-5236. [CrossRef]

26. Caporaso, J.G.; Lauber, C.L.; Walters, W.A.; Berglyons, D.; Lozupone, C.A.; Turnbaugh, P.J.; Fierer, N.; Knight, R. Global patterns of $16 \mathrm{~s}$ rRNA diversity at a depth of millions of sequences per sample. Proc. Natl. Acad. Sci. USA 2011, 108, 4516-4522. [CrossRef] [PubMed]

27. Zhou, X.; Liu, X.; Huang, S.; Cui, B.; Liu, Z.; Yang, Q. Total inorganic nitrogen removal during the partial/complete nitrification for treating domestic wastewater: Removal pathways and main influencing factors. Bioresour. Technol. 2018, 256, 285. [CrossRef] [PubMed]

28. Nikolaus, K.; Ulf, T.; Möbius, C.H. Enhancement of capacity and efficiency of a biological waste water treatment plant. Water Sci. Technol. 1999, 40, 11-12. [CrossRef]

29. Prosser, J.I. Autotrophic nitrification in bacteria. Adv. Microb. Physiol. 1989, 30, 125-181. [CrossRef] [PubMed]

30. Rodríguez-Sánchez, A.; Leyva-Díaz, J.C.; Poyatos, J.M.; González-López, J. Performance and kinetics of membrane and hybrid moving bed biofilm-membrane bioreactors treating salinity wastewater. AIChE J. 2017, 63, 3329-3342. [CrossRef]

31. Martín-Pascual, J.; Reboleiro-Rivas, P.; López-López, C.; Leyva-Díaz, J.C.; Jover, M.; Muñio, M.M.; González-López, J.; Poyatos, J.M. Effect of the Filling Ratio, MLSS, Hydraulic Retention Time, and Temperature on the Behavior of the Hybrid Biomass in a Hybrid Moving Bed Membrane Bioreactor Plant to Treat Urban Wastewater. J. Environ. Eng. 2015, 141, 04015007. [CrossRef]

32. Chatterjee, P.; Ghangrekar, M.M.; Rao, S. Organic matter and nitrogen removal in a hybrid upflow anaerobic sludge blanket-Moving bed biofilm and rope bed biofilm reactor. J. Environ. Chem. Eng. 2016, 4, 3240-3245. [CrossRef]

33. Liu, Y.; Li, J.; Guo, W.; Ngo, H.H.; Hu, J.; Gao, M.T. Use of magnetic powder to effectively improve the performance of sequencing batch reactors (SBRs) in municipal wastewater treatment. Bioresour. Technol. 2018, 135-139. [CrossRef]

34. Özkan, O.; Uyanık, İ. Effect of Membrane Type for the Treatment of Organized Industrial Zone (OIZ) Wastewater with a Membrane Bioreactor (MBR): Batch Experiments. Water 2017, 9, 582. [CrossRef]

35. Chai, C.; Zhang, D.; Yu, Y.; Feng, Y.; Wong, M. Carbon Footprint Analyses of Mainstream Wastewater Treatment Technologies under Different Sludge Treatment Scenarios in China. Water 2015, 7, 918-938. [CrossRef]

36. Yang, B.; Wang, J.; Wang, J.; Xu, H.; Song, X.; Wang, Y.; Li, F.; Liu, Y.; Bai, J. Correlating microbial community structure with operational conditions in biological aerated filter reactor for efficient nitrogen removal of municipal wastewater. Bioresour. Technol. 2017, 250, 374-381. [CrossRef]

37. Wang, X.; Hu, M.; Xia, Y.; Wen, X.; Ding, K. Pyrosequencing analysis of bacterial diversity in 14 wastewater treatment systems in china. Appl. Environ. Microb. 2012, 78, 7042. [CrossRef]

38. Zhang, T.; Shao, M.F.; Ye, L. 454 pyrosequencing reveals bacterial diversity of activated sludge from 14 sewage treatment plants. ISME J. 2012, 6, 1137-1147. [CrossRef]

39. Ibarbalz, F.M.; Figuerola, E.L.; Erijman, L. Industrial activated sludge exhibit unique bacterial community composition at high taxonomic ranks. Water Res. 2013, 47, 3854-3864. [CrossRef] 
40. Ivnitsky, H.; Katz, I.; Minz, D.; Volvovic, G.; Shimoni, E.; Kesselman, E.; Semiat, R.; Dosoretz, C.G. Bacterial community composition and structure of biofilms developing on nanofiltration membranes applied to wastewater treatment. Water Res. 2007, 41, 3924-3935. [CrossRef]

41. Miura, Y.; Watanabe, Y.; Okabe, S. Membrane biofouling in pilot-scale membrane bioreactors (MBRs) treating municipal wastewater: Impact of biofilm formation. Environ. Sci. Technol. 2007, 41, 632-638. [CrossRef] [PubMed]

42. Jia, L.; Gao, X.; Chen, Y.P.; Zhai, X.M.; Guo, J.S.; Fan, Y. Studies on excess sludge reduction and microbial community growing in a novel A+OSA reactor. Environ. Eng. Manag. J. 2013, 12, 2097-2105. [CrossRef]

43. Larsen, P.; Nielsen, J.L.; Otzen, D.; Nielsen, P.H. Amyloid-like adhesins produced by floc-forming and filamentous bacteria in activated sludge. Appl. Environ. Microb. 2008, 74, 1517-1526. [CrossRef] [PubMed]

44. Wang, J.; Rong, H.; Zhang, C. Evaluation of the impact of dissolved oxygen concentration on biofilm microbial community in sequencing batch biofilm reactor. J. Biosci. Bioeng. 2018, 125, 532-542. [CrossRef]

45. Ye, L.; Shao, M.F.; Zhang, T.; Tong, A.H.; Lok, S. Analysis of the bacterial community in a laboratory-scale nitrification reactor and a wastewater treatment plant by 454-pyrosequencing. Water Resh. 2011, 45, 4390-4398. [CrossRef]

46. Yue, X.; Yu, G.; Lu, Y.; Liu, Z.; Li, Q.; Tang, J.; Liu, J. Effect of dissolved oxygen on nitrogen removal and the microbial community of the completely autotrophic nitrogen removal over nitrite process in a submerged aerated biological filter. Bioresour. Technol. 2018, 254, 67-74. [CrossRef]

47. Caporaso, J.G.; Bittinger, K.; Bushman, F.D.; DeSantis, T.Z.; Andersen, G.L.; Knight, R. PyNAST: A flexible tool for aligning sequences to a template alignment. Bioinformatics 2009, 26, 266-267. [CrossRef]

48. Abdel-El-Haleem, D. Minireview Acinetobacter: Environmental and biotechnological applications. Afr. J. Biotechnol. 2003, 2, 312. [CrossRef]

49. Deinema, M.H.; Loosdrecht, M.V.; Scholten, A. Some physiological characteristics of acinetobacter spp. accumulating large amounts of phosphate. Water Sci. Technol. 1985, 17, 119-125. [CrossRef]

50. Abd-Elsalam, H.E.; Hafez, E.E.; Zaki, E.A. Naphthalene and phenol degradation by flavobacterium sp. DQ398100 and pseudomonas putida, DQ399838 isolated from petroleum polluted soil. Acta Geochim. 2006, 25, 83-84. [CrossRef]

51. Dai, Q.; Liu, R.; Liang, Y.T.; Shu, X.M.; Can-Can, X.U.; Chen, L.J. Influence of ciprofloxacin on the microbial community and antibiotics resistance genes in a membrane bioreactor. Environ. Sci. 2018, 3, 1333-1341. [CrossRef]

52. Dong, X. Acetanaerobacterium. Bergey's Man. Syst. Archaea Bact. 2015, 1-3. [CrossRef]

53. Daims, H.; Lebedeva, E.V.; Pjevac, P.; Han, P.; Herbold, C.; Albertsen, M.; Jehmlich, N.; Palatinszky, M.; Vierheilig, J.; Bulaev, A.; et al. Complete nitrification by Nitrospira bacteria. Nature 2015, 528, 504-509. [CrossRef] [PubMed]

54. Slaveykova, V.I.; Pinheiro, J.P.; Floriani, M.; Garcia, M. Interactions of core-shell quantum dots with metal resistant bacterium cupriavidus metallidurans: Consequences for $\mathrm{cu}$ and $\mathrm{pb}$ removal. J. Hazard. Mater. 2013, 261, 123-129. [CrossRef] [PubMed]

55. Fukuoka, K.; Tanaka, K.; Ozeki, Y.; Kanaly, R.A. Biotransformation of indole by Cupriavidus sp. strain KK10 proceeds through $\mathrm{N}$-heterocyclic- and carbocyclic-aromatic ring cleavage and production of indigoids. Int. Biodeter. Biodegr. 2015, 97, 13-24. [CrossRef]

(C) 2020 by the authors. Licensee MDPI, Basel, Switzerland. This article is an open access article distributed under the terms and conditions of the Creative Commons Attribution (CC BY) license (http://creativecommons.org/licenses/by/4.0/). 